\title{
Prevalence of Pediculosis capitis Among Elementary School Children in Kabupaten Ciamis
}

\author{
$1^{\text {st }}$ A Nurmalasari \\ STIKES Muhammadiyah Ciamis \\ Ciamis, Indonesia \\ arynurmalasari@stikesmucis.ac.id
}

\author{
$2^{\text {nd }}$ A Farihatun \\ STIKES Muhammadiyah Ciamis \\ Ciamis, Indonesia
}

Abstract-Pediculosis is an ectoparasitic infestation by Pediculus humanus capitis (hair lice) which causes health problems, especially in elementary school children. Head lice infestation can cause itching and can cause other complications if the presence of head lice is considered to have a high enough severity. Besides causing clinical symptoms, head lice infestation can cause psychological disorders like shyness. This study aims to determine the prevalence of head lice infestation in elementary school children in Kabupaten Ciamis. This research lasted for 2 months from July to August 2019 to 612 elementary school children, 307 girls, 305 boys from 25 selected elementary schools in Kabupaten Ciamis. Pediculosis capitis is defined as the presence of adult lice, nymphs, and eggs in head hair. In total, head lice infestations were found in $229 / 612(37 \%)$, $182 / 229(79 \%)$ on girls and 47/229 (21\%) on boys. Pediculosis is a public health problem that occurs in elementary school children and needs attention in Kabupaten Ciamis.

Keywords-Pediculosis capitis, Elementary School Children, Kabupaten Ciamis

\section{INTRODUCTION}

Based on its taxonomy, Pediculus humanus capitis belongs to the Insect Class, Order Anoplura, Family Pediculidae, Genus Pediculus. Infest certain mammals more than 550 species. Three unique species of the genus Pediculus are known as obligate parasites in humans, the head louse, body louse, and crab (pubic) louse. Officially the parasitic epidemiology that infects the human body can act as an important vector of diseases in humans such as typhoid epidemics, trench fever, and head lice - fever recurrence.[1]

Pediculus humanus capitis has a Dorso-ventral flat shape with a size of $1.0-1.5 \mathrm{~mm}$, gray, triangular head, united thoracic segments, and a segmented abdomen. The tip of each foot equipped with nails (figure 1). Eggs (nits) are white, attached to the hair with chitin adhesive (cement-like chitin).[2] The growth period of head lice from eggs to adulthood is about 18 days and adult lice can live for 30 days and cannot survive without blood after 1520 hours. [3] Head lice can switch from one host to another through direct contact.[2] Pediculus humanus capitis feet are designed to grip hair and can walk $2-3 \mathrm{~cm}$ per minute. Pediculus humanus capitis can live 1-2 days outside the head while the eggs can survive last up to 10 days. [4] Clinical symptoms felt by sufferers are itching in the area affected by the bite. Louse saliva that stimulates red papules and causes itching. In severe infestations, the hair will stick to each other and harden, and many adult fleas, eggs and pus exudates are found, which are caused by inflamed bites and can also be covered with fungus. This situation is called plica palonica. [2]
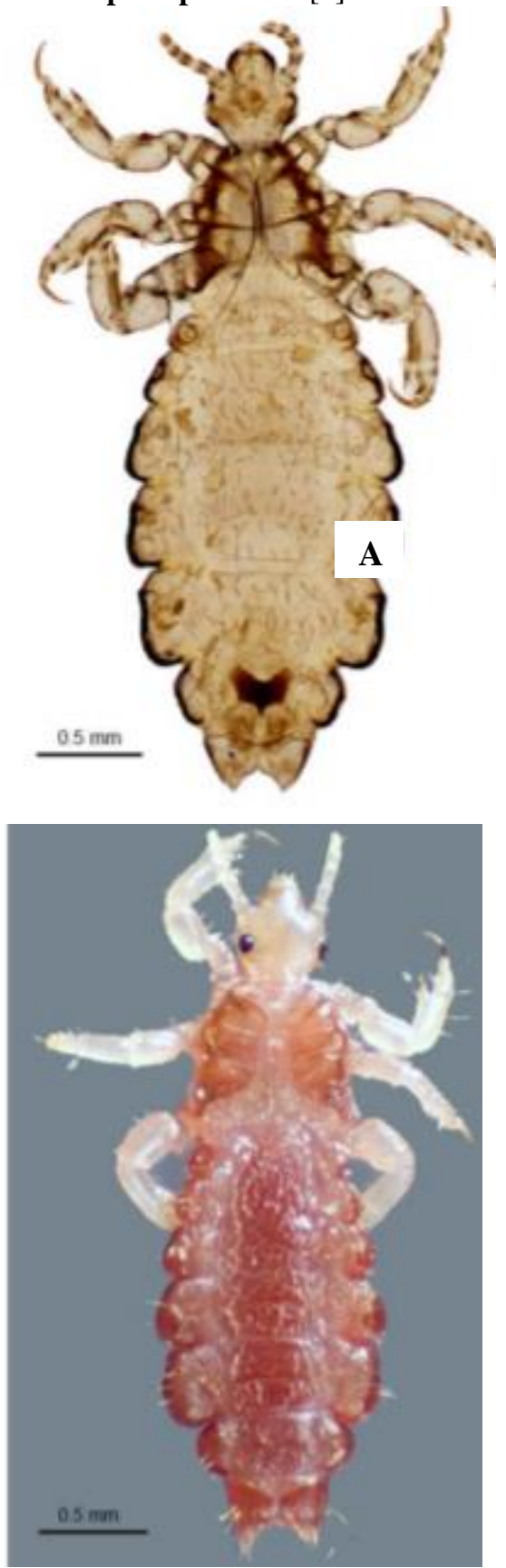

Figure 1. Adult Head Lice. A. Ventral view female head lice. B. Dorsal view female head lice [1] 
Elementary school-age children are one of the growth and development phases, wherein this phase the children are aged 6-13 years.[5][6] At this age, children do not have independence in terms of hygiene personnel. Besides being able to be used as a disease vector. So often children do not pay attention to their cleanliness and have great potential to be infested with ectoparasites. [6] [7]

\section{MATERIALS AND METHODS}

This study aims to determine the prevalence of head lice infestation among elementary school-age children in Ciamis Regency.

The research method used was cross-sectional. The technique of collecting data is observational. The tool used is a serit comb. Head lice examination is by combing head hair. From front to back. Starting from the left, middle, and right side of the head. The criteria for a diagnosis of pediculosis were the presence of at least one living adult, nymph, or viable nit.[8]

The population in this study were all elementary school children in Kabupaten Ciamis. The sample used in this study taken randomly. The minimum sample size determined using the Slovin formula is 398 samples, but in this study, the researchers managed to collect a sample of 612 respondents. Sampling was chosen by randomly selecting 9 Kecamatan, which were considered to represent 27 Kecamatan in Kabupaten Ciamis, then 25 elementary schools were determined in the 9 Kecamatan. The next stage proportionally determined the number of children who will be respondents and respondents selected randomly.

\section{RESULTS AND DISSCUSSION}

Tabel 1. Pediculosis examination result

\begin{tabular}{|c|c|c|c|}
\hline & Responden & Pediculosis & Pediculosis (\%) \\
\hline Boys & 305 & 47 & 21 \\
\hline Girls & 307 & 182 & 79 \\
\hline Total & 612 & 229 & 37 \\
\hline
\end{tabular}

A total of 612 students examined (307 girls and 305 boys), among which only 229 students showed pediculosis and the total prevalence rate was $37 \%$. Pediculosis was more frequent in girls. Girls have longer hair compared to boys.[9] Pediculus capitis can stick to the hair. Other factors that influence the presence of Pediculus capitis are the frequency of washing hair less than three times a week and poor personal hygiene.

Head lice infestation is one of the significant public health problems with a worldwide distribution. The lack of data on the epidemiology of head lice could hamper and disrupt the strategy for pediculosis control in Kabupaten Ciamis. The highest percentage of this incidence seen in children aged five to twelve years.

The prevalence of head lice in children found in this study was 37\% (79\% girls and $21 \%$ boys). The results of this study are consistent with other studies carried out in Iran where the rate of contamination was reported to be $4.8 \%$ in Khaje City, including $6.66 \%$ girls and $2 \%$ boys.[9] Children aged 10-11 years most frequently infested with pediculosis, which explain because of their age and head-to-head contact.[9] Head lice infestation was observed to be a common condition among elementary school children, as having been documented by others.[10] Pediculosis is more common in girls because girls have long hair compared to boys. Pediculus humanus capitis has legs that can hold onto the hair. Long hair becomes a potential place for head lice to store more eggs.

Good knowledge does not affect someone not infected with pediculosis. This is because transmission can occur through direct physical contact.[11] Physical contacts, especially head-to-head contact are the most important factors in transmission of head lice infestation.[9]

The percentage of Pediculosis in primary school children as much as $37 \%$, shows this is a severe problem that must be a concern, especially by the Ciamis District Health Office. It knows in several journals that Pediculus humanus capitis is a vector of several diseases such as typhoid, trench fever, and so on. [1] This research has never been done in Ciamis District. Considering this is very important, it hopes that further research related to Pediculus humanus capitis can be carried out.

\section{CONCLUSION}

The prevalence of Pediculosis capitis in elementary school children in Kabupaten Ciamis is $37 \%$ were infected with lice, $79 \%$ girls and $21 \%$ boys.

\section{ACKNOWLEDGMENTS}

A thank you is given to Kemenristekdikti for providing this research assistance fund, and a thank you to the STIKesMuhammadiyah Ciamis for supporting this research.

\section{REFERENCES}

[1] D. L. Bonilla, L. A. Durden, M. E. Eremeeva, and G. A. Dasch, "The Biology and Taxonomy of Head and Body LiceImplications for Louse-Borne Disease Prevention," PLoS Pathog., vol. 9, no. 11, 2013.

[2] S. P. D. P. FKUI, Buku Ajar Parasitologi Kedokteran FKUI, Keempat. Jakarta: FKUI Press, 2011.

[3] M. V. Rumampuk, "Peranan Kebersihan Kulit Kepala dan Rambut Dalam Penanggulangan Epidemiologi Pediculus humanus capitis," J. Ners, vol. Vol. 9 No., pp. 35-42.

[4] Soedarto, Buku Ajar Parasitologi Kedokteran. Jakarta: CV. Sagung Seto, 2011.

[5] M. Moshki, F. Zamani-Alavijeh, and M. Mojadam, "Efficacy of peer education for adopting preventive behaviors against head lice infestation in female elementary school students: A randomised controlled trial," PLoS One, vol. 12, no. 1, pp. 1-12, 2017.

[6] S. Sayyad, A. Vahabi, B. Vahabi, M. Sayyadi, and M. Ahmadian, "Head louse (Pediculus humanus capitis) infestation in primary schoolchildren in rural areas of Paveh County, Kermanshah province," J. Chem. Pharm. Sci., vol. 2016, no. 7, pp. 35-38, 2016.

[7] R. Mastectomy, "Artikel Penelitian keluarga," vol. 3, no. 38, pp. 146-154, 2015.

[8] M. Nazari, R. Goudarztalejerdi, and M. Anvari Payman, "Pediculosis capitis among primary and middle school children in Asadabad, Iran: An epidemiological study," Asian Pac. J. Trop. Biomed., vol. 6, no. 4, pp. 367-370, 2016.

[9] A. Vahabi et al., "Prevalence and risk factors of Pediculus (humanus) capitis (Anoplura: Pediculidae), in primary schools in Sanandaj city, Kurdistan province, Iran," Trop. Biomed., vol. 29, no. 2, pp. 207-211, 2012.

[10] B. L. Frankowski et al., "Clinical report - Head lice," Pediatrics, vol. 126, no. 2, pp. 392-403, 2010.

[11] R. AISY, "Hubungan Tingkat Pengetahuan dan Perilaku 
Pencegahan Terhadap Angka Kejadian Penyakit Pediculosis capitis," Fak. Kedokt. Univ. MUHAMMADIYAH SURAKARTA, no. September, pp. 160-164, 2018. 